\title{
Motivations for Obtaining and Redeeming Coupons from a Coupon App: Customer Value Perspective
}

\section{Hong Joo Lee ${ }^{1}$ and Joon Yeon Choeh ${ }^{2}$}

1 The Catholic University of Korea, School of Business Administration, Bucheon, Republic of Korea, hongjoo@catholic.ac.kr

2 Sejong University, Department of Software, Seoul, Republic of Korea, zoon@sejong.edu

Received 23 September 2019; received in revised form 27 April 2020; accepted 8 June 2020

\begin{abstract}
Mobile coupons have significantly enhanced marketing and e-commerce. To assess the benefits of mobile coupon apps, which are unavailable with traditional coupons, we examined users' motivations for obtaining and redeeming mobile bonus coupons from a customer value perspective. We collected coupon issue and redemption data from a mobile coupon app and used it to analyze the effects of various factors on coupon issue and redemption. Using the days of coupon issue as a control variable, we tested bonus-type and buy-one-get-onefree-type coupons separately. We applied negative binomial regression for the tests and used a standardized number of issuing days, face value, price, and brand popularity. Our findings indicate that a coupon's functional (face value and product price) and social (brand popularity) values significantly affect mobile coupon issue and redemption. Furthermore, the effects of social value on coupon issue and redemption vary by coupon type-bonus or buy-one-get-one-free. These results can help marketing and e-commerce practitioners to take advantage of the benefits of issuing the optimal mobile coupons for the right products.
\end{abstract}

Keywords: Mobile coupon, Customer value, Face value, Product price, Brand popularity 


\section{Introduction}

Due to the immediacy of mobile phones, which makes them an effective communication device for reaching consumers, mobile coupons have become one of the fastest-growing promotional channels used by retailers [2], [25], [26], [30], [42]. Mobile coupons are offers of financial discount or rebate that consumers receive electronically through mobile devices. Mobile coupons may take the form of texts, pictures, videos, or barcodes and can be downloaded, saved, and redeemed online or at retail stores [49]. Retailers use mobile coupons to introduce new products, encourage bulk purchases, increase trial rates, ensure higher off-take of slow-moving products, promote sales to prevent excesses in inventory, and improve attendance at promotional events [9], [49].

Due to the increasing popularity of mobile coupons over paper coupons [55], researchers have explored how consumer attitudes [21], [57] and marketing variables [9] affect redemption rates. The effects of perceived effort, perceived control, fear of spam, timing, content, and nature of product have been investigated through surveys conducted among mobile coupon users.

However, existing studies on the use of mobile coupon apps and bonus coupons are scarce [51], and most studies on mobile coupons have been conducted through surveys and experiments with panels [30], [31], [39], [40], [63], [70]. In earlier studies, the dependent variables typically used in surveys were consumers' attitudes toward or behavioral intention to use coupons [31], since researchers had no access to usage data. Although surveys and experimental research methods are useful for identifying the impact of certain variables, analyzing customer behavior based on real data can confirm their effects and provide different perspectives on coupon usage. For example, analysis of coupon app data can reveal all the coupons that consumers have downloaded and redeemed. The effects of various factors on coupon acquisition and redemption may be compared based on the actual data.

Mobile devices are highly personalized and immediate and offer almost continuous access to consumers. As such, they have become the preferred method with which marketers advertise to and reach potential customers [5], [21], [30]. Coupon apps, such as RetailMeNot and VoucherCodes, are platforms that connect retailers wishing to promote their businesses among users who wish to gain benefits [19]. Owners of small stores can easily register and issue their coupons via such apps. The convenience of issuing and redeeming coupons via coupon apps has allowed many small establishments that were previously unable to publish their own coupons and reach potential customers due to initial costs to take advantage of that marketing strategy. The acquisition of coupons from coupon apps is a pull process-users navigate through various categories and locations to get the coupons they wish to use. Occasionally, coupon apps may suggest coupons based on the user's location and previous history. Local stores prefer to issue bonus coupons-that is, coupons offering free products with the purchase of a certain item-rather than discount coupons [49]. Small stores usually issue coupons not to promote sales or prevent excess inventory, but to increase awareness of their business in the local area.

The goal of this paper is to identify the motivations behind customers' acquisition and redemption of bonus coupons from a mobile coupon app using customer value theory. Customer value theory has been applied to explain customers' purchasing decisions in various fields [37] and provides a framework for listing and organizing factors according to their value. This paper confirms the effects of factors identified in earlier studies within the scope of the customer value theory and sheds light on how customers make purchase decisions in the context of acquiring and choosing to redeem mobile coupons. Coupon acquisition and redemption data from a mobile coupon app were analyzed to compare the effects of factors between obtaining and redeeming coupons, and the roles of functional and social values, such as the motivational factors of bonus coupon use, were analyzed. The product prices and face values of coupons were used as measures of functional value, and brand popularity was measured according to the number of searches on a Korean portal site to assess social value. This study is guided by two specific research questions, as follows:

RQ1: How does the functional value of coupons in terms of price and face value affect acquisition and redemption of the coupons in a mobile coupon app?

RQ2: How does the social value of coupons in terms of brand popularity and number of searches affect acquisition and redemption of the coupons in a mobile coupon app?

Our findings suggest that functional value positively influences coupon acquisition and redemption, while social value only has a positive effect on coupon acquisition. However, the effects differed according to coupon type: bonus coupons are affected in both aspects, but social value was not associated with any significant impact on coupon acquisition and redemption for buy-one-get-one-free-type coupons.

Overall, the study makes the following contributions: First, the study highlights the complex role of social value in coupon acquisition and redemption and reveals that coupon type also influences customer behavior. Second, actual data from users of a coupon app were collected and analyzed, including around seven thousand coupons and three hundred thousand users. Thus, it was possible to investigate the role of motivational factors in coupon acquisition. Most coupon studies have focused on redemption due to the absence of data or research targeted toward coupon issuers. Although coupon acquisition involves similar motivational factors to coupon redemption, social value plays 
different roles. In the section that follows, existing studies on mobile coupons and motivational factors for coupon use are summarized; this is followed by the research model and hypotheses, data analysis and results, and discussion and implications.

\section{Conceptual Background}

In this section, previous studies on mobile coupon service and coupon redemption factors are summarized. A mobile coupon is not a digital form of a paper coupon but transforms the entire couponing process through mobile coupon apps. Also, customer value theory, the theoretical lens of this study, is described, and its application to other relevant fields are also discussed.

\subsection{Mobile Coupon Service}

A mobile coupon is a subcategory of mobile marketing that possesses the following characteristics: ubiquity, location/situation-sensitivity, time-sensitivity, personalization, and convenience [30], [35], [36], [60]. Public acceptance of various mobile marketing practices has been verified in earlier studies [12], [30], [66], [69], including the role [57] and extent of adoption [53] of mobile advertising in the marketing mix of corporations. Mobile marketing practices vary according to format (text, image), application (banner ads, coupons, posters), delivery (SMS, mobile apps), and context-sensitivity (location-based or otherwise) [10]. Mobile marketing has also gained traction in the retail industry, particularly in relation to customer loyalty and customer relationship management [72], through SMS-based promotional coupons [10] and mobile applications [33]. However, despite the convenience and value that mobile coupons offer, perceived risks and trust issues caused by privacy concerns hinder their usage [34], [73].

The Mobile Marketing Association [49] has broken down the couponing process into delivery, redemption, and clearing. Delivery refers to how the user receives the coupon, which may be a pull process (i.e., users must act to acquire a mobile coupon) or a push process (i.e., the coupon is automatically sent to users). Customers can receive the coupon via short message service (SMS), multimedia messaging service (MMS), application, or e-mail. Next, the coupon can be redeemed offline using a code or in real time through a machine containing a scanner. Offline redemptions require merchants to deliver printed coupons for clearing, whereas real-time redemptions are cleared automatically.

Diverse coupon apps disseminate digital coupons and help the entire couponing process [19]. Certain mobile coupon apps support retailers through the couponing process and alleviate search costs for coupon users. Store owners can easily use mobile apps to create mobile coupons by entering their information and coupon characteristics, such as face value and conditions of use. Users of coupon apps can navigate categories of services and products or store locations and save coupons for later use. Saved coupons are redeemed in store by scanning coupon images from users' smartphones, and the coupons are cleared in real time by the apps' operators. In this study, coupon issue and redemption data were collected from a mobile coupon app based in South Korea that functions as just described.

\subsection{Coupon Redemption Factors}

Coupons allow consumers to purchase promoted products at lower prices [48]. Existing research has identified several motivations behind coupon use, including psychological and economic benefits [3], [54], in addition to the utilitarian and hedonic perceptions of benefits [17].

In the context of traditional economic theory, consumers are interested in price deals because of the resulting financial incentive and will consistently choose to pay a lower price as long as the amount saved is sufficiently large to compensate for any tangible costs [3], [65] . Several theories have sought to define the relationship between discount size and likelihood of purchase, as influenced by the consumer's perception of savings and the product's perceived value and utility [1], [50]. Since consumers do not wish to regret not having used coupons, the expiration effect of coupons can induce a second peak in the redemption pattern immediately prior to the expiration date [32].

Earlier studies have identified psychological benefits related to price deals, such as the feelings associated with smart and responsible shopping [48], [58], [59] or being able to gain social recognition for being economically savvy and therefore a good shopper [6], [43], [62]. Price deals and coupons also offer hedonic benefits, such as amusement, entertainment, and novelty [3], [9], or opportunities to try newly launched products [17]. However, despite the benefits of couponing, Ashworth et al. [3] argued that price deals can also carry social disincentives, specifically the aversion to appearing cheap or stingy-a direct contradiction of consumers' economic goals. Several studies have identified the characteristics of coupon-prone customers [13], [67], and their findings suggest that coupon use depends on the consequent benefits versus the possible social costs that the consumer will incur.

The discount format denotes how a coupon or discount is presented to influence the consumer's perception of the product's value function, which, in turn, is expected to significantly affect redemption [9], [20]. Discounts take various forms, and each type is best used in specific situations. For example, coupons may offer a percentage or monetary amount off the price or offer freebies or extra products with purchase. Percentages or money off are easy to factor into product prices and contribute to the consumer's projection of themselves as a smart shopper [8], [9]. However, other 
studies have shown that consumers actually prefer non-monetary benefits, such as freebies or extra product promotions [9], because their actual value is difficult to calculate, and therefore the buyer perceives the free item as something extra to the actual price of the product [18], [52]. Brand loyalty, characteristics of purchase (quantity, store location, weekdays), and concurrent promotional conditions (advertising, price change) also affect coupon redemption [28].

Promotion timing is vital to redemption rates because when consumers receive advertising messages directly, their perception of relevance and message processing are affected [7], [46]. Time in this context bears stronger relation to the tasks associated with marketing messages than to clock time-messages received during leisure time garner more motivated attention than promotions received during work [11], [16].

Chandon et al. [17] proposed a benefit congruency framework on the premise that the efficacy of sales promotions is influenced by the similarity between the benefits they offer and the corresponding promoted product. Banerjee and Yancey [9] found that matching the benefits offered to the product category improves redemption: monetary benefits match utilitarian products, and non-monetary benefits fit with hedonic experiential products. Other studies found that coupon redemption increased with proximity to the promoted shop [14] or restaurant [64], as proximally located retailers are more likely to be clicked on in mobile-based internet searches [24], and real-time coupons increase unplanned spending in in-store settings [29]. With regards to temporal and geographical mobile targeting, Luo et al. [45] found that same-day targeting is more useful for close-distance promotions, whereas one-day prior to targeting is more useful for far-distance promotions. For in-store competing coupon situations, appropriate targeting, price range, and loyalty are indispensable for increasing redemption rates [47].

Most earlier studies of the motivational factors that affect coupon usage were based on surveys or experiments. The findings from these studies must be validated with actual data where possible, and different variables and measures from the data or external sources may also be used to test the relationships. In this study, coupon data, including coupon characteristics, acquisition and redemption ratios, and external data including product price and brand popularity, were used in the analysis.

\subsection{Customer Value Theory}

As discussed above, the motivational factors affecting coupon usage are diverse and have many dimensions. While some of these factors may be sorted according to various aspects, it is challenging to organize all factors within a single classificatory scheme. Therefore, customer value theory was applied in this study as a guideline to list and categorize factors focusing on the scope determined by the research questions.

Customer value is an essential predictor of customer purchase decisions, as the existing marketing and e-commerce literature illustrates [4], [22], [37], [38], [61]. The perceived value of a product or service is the consumer's assessment of its utility, which is determined based on comparison perceptions of what the consumer receives with what they give [75], usually based on a trade-off between functional quality and monetary price. Nonetheless, the multi-dimensionality of value has been investigated in efforts to further understand its different aspects, because a definition of value as quality versus price is too simplistic [61], [68], [75]. Sweeney and Soutar [68] identified four stable dimensions of value: emotional, social, functional price (value for money), and functional quality.

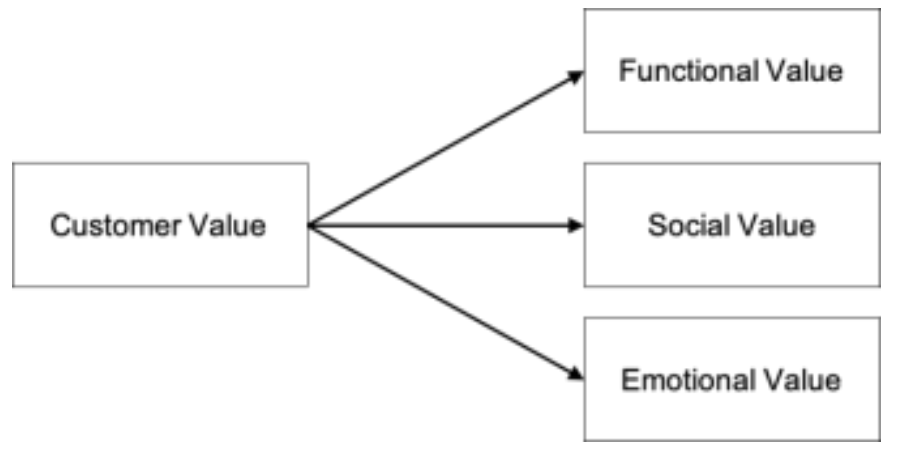

Figure 1: Value framework

Figure 1 shows the value framework based on customer value research [61], [68]. Emotional value is an item's hedonic or experiential value, the perceived utility derived from the item's capacity to generate specific feelings or affective states in the consumer. Social value is the perceived utility of a product based on its ability to enhance the customer's social self-concept or well-being. Consumers purchase products based on how they view themselves or how they wish to be seen in their social circles; thus, social value relates to a product's ability to enhance or express the user's selfimage. Because the purchase of a particular product carries a social meaning for the buyer [39], brand choices can be significant. 
The functional value has two aspects: price and quality. Functional value for price is the perceived utility derived from the product considering its costs, and functional value for quality is the perceived utility derived from its performance attributes, such as reliability and durability. Mobile coupons enhance a product's functional value for price by offering discounts, freebies, or a buy-one-get-one-free deal. The customer perceives the coupon as having a high functional value because it lowers the product's cost and gives greater value for money compared to purchase of the same product without the coupon.

\section{Research Model and Hypotheses}

In this study, customer value theory was applied to investigate the relationship between coupons' characteristics and their acquisition or redemption. The focus of this study is on customers' mobile coupon acquisition and redemption decisions based on the coupons' perceived functional and social value, operationalized as face value, product price, and brand popularity, as shown in Figure 2.

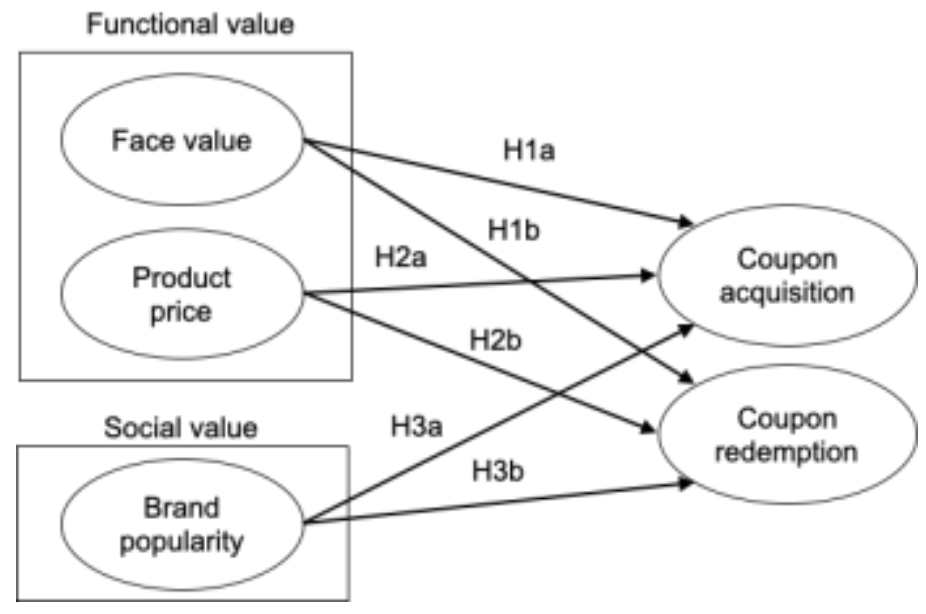

Figure 2: Research framework

A coupon's face value is the amount of discount that it offers [56], a functional value that contributes positively to the customer's desire to acquire and eventually redeem the coupon. Customers perceive greater value for money if they can obtain higher discounts [21]. Therefore, the greater the price utility, the higher the customer's mobile coupon acquisition and redemption intention. The face value of a coupon affects a customer's decision to save it on the app because a high discount gives the perception of a higher value for money. The relationship between the discount amount and the likelihood of coupon redemption is influenced by how consumers perceive savings and the product's perceived value and utility [1], [50]. Hence,

H1a: The face value of a mobile bonus coupon positively affects the likelihood that consumers will acquire the coupon.

H1b: The face value of a mobile bonus coupon positively affects the likelihood that consumers will redeem the coupon.

After the mobile coupon's face value, the perceived value of a mobile bonus coupon will be most influenced by its effect on the product's total price. The perceived functional value of a mobile coupon's price utility may be negatively affected by the actual price that remains to be paid by the customer, however great the discount. Price and price perceptions significantly affect coupon redemption [44]. When the price of a product increases, coupon redemptions for that product decline [41]. While a high face-value discount might initially seem attractive, it is less likely to be redeemed if the price of the actual item remains too high for the customer. Hence,

H2a: The price of a product for purchase with a mobile bonus coupon negatively affects the likelihood that consumers will acquire the coupon.

H2b: The price of a product for purchase with a mobile bonus coupon negatively affects the likelihood that consumers will redeem the coupon.

Customers derive social value and express their self-image through their consumption of various products. The purchase of an item is a social act that expresses symbolic meanings, social codes, relationships, consumer identity, and ego [38]. Buying high-quality products from popular brands at a fraction of the original price can contribute to the consumer's perceptions of themselves as a smart and responsible shopper [48], [58], [59]. One way in which mobile coupons can help users to express or enhance their self-image is by contributing to their ability to gain social recognition as being economically savvy-good shoppers [6], [62]-and by making popular brands available to them. Therefore, the product's brand popularity may affect a mobile coupon's acquisition and redemption. Hence, 
H3a: The brand popularity of a product on a mobile bonus coupon positively affects the likelihood that consumers will acquire the coupon.

H3b: The brand popularity of a product on a mobile bonus coupon positively affects the likelihood that consumers will redeem the coupon.

\subsection{Data}

Data were collected from a Korean mobile coupon company to test the hypotheses outlined in Section 3. The company operates a mobile app platform that delivers coupons to its users. Users can search or navigate the mobile app using categories and the locations of participating stores and outlets. If a user finds a coupon s/he wants, the mobile app will issue it, and the user can save it for later use. The app issues coupons for food and restaurants, desserts, drinks, and beauty, lifestyle, and leisure stores. The coupons on the app are not manufacturers' coupons; they are usually from retailers and local stores. The data includes coupons issued to and redeemed by all users, coupon type, and product information for food and restaurants from July to October 2014. The dataset contains 6,823 coupons issued 878,239 times. 297,220 users saved coupons, and their average age is 21.745 .

The dataset concerns two types of coupon: the bonus coupon, which offers other products for free with the purchase of a certain item, and the buy-one-get-one-free coupon. Although the buy-one-get-one-free coupon is a type of bonus coupon, the face values and product prices are equal for the buy-one-get-one-free coupon. Thus, bonus and buy-oneget-one coupons were classified separately to identify the differences between them. Coupons issued more than ten times were included in the data set for analysis. Coupons with unclear or non-existent brand popularity or price information were eliminated, which left 3,193 coupons for analysis. Table 1 presents the descriptive statistics for the data.

Table 1: Descriptive statistics

\begin{tabular}{|c|c|c|c|}
\hline \multirow{3}{*}{$\begin{array}{l}\text { Variables } \\
\text { Number of coupons analyzed }\end{array}$} & \multicolumn{3}{|c|}{ Descriptive statistics } \\
\hline & All & Bonus & $\begin{array}{l}\text { Buy-one get-one- } \\
\text { free }\end{array}$ \\
\hline & 3,193 & 2,662 & 531 \\
\hline $\begin{array}{l}\text { Average days of coupon issue } \\
\text { (standard deviation) }\end{array}$ & $63.05(33.24)$ & $64.96(32.38)$ & $53.5(35.79)$ \\
\hline Average product price & $8,581(5,679.90)$ & $9,517(5,720.24)$ & $3,888(1,882.58)$ \\
\hline Average face value & $3,199(2,270.78)$ & $3,062(2,316.47)$ & $3,888(1,882.58)$ \\
\hline Average number of coupons issued & $173.3(224.02)$ & $169.6(185.09)$ & $192.1(360.30)$ \\
\hline $\begin{array}{l}\text { Average number of coupons } \\
\text { redeemed }\end{array}$ & $61.76(89.22)$ & $61.33(81.63)$ & $63.91(120.34)$ \\
\hline Average redemption rate & $0.3268(0.1489)$ & $0.3378(0.1444)$ & $0.2716(0.1585)$ \\
\hline Average value of brand popularity & $29.22(59.97)$ & $28.57(63.43)$ & $32.48(38.04)$ \\
\hline
\end{tabular}

(Note. Product price and face value are in KRW and 1 US dollar is around 1,100-1,200 KRW. The values in parentheses are standard deviations.)

Days of coupon issue indicate the number of days during which a coupon may be issued or saved. The redemption rate is the ratio of the number of coupons redeemed to the number of coupons issued. Face value is the absolute value of the discount, and the price is the product's original price. If a coupon is applicable for only one product, the price of that item was used. If a coupon applies to several products, the average price of all relevant products was used. Since no published brand popularity index has been established for many local and small stores, brand popularity was computed using the products' brand comparative values based on the number of searches on the Korean search engine Naver.com. For example, for a coupon for a latte in a cafe, the number of searches for the cafe was used as the brand popularity value. Like Google Trends, Naver does not show the exact number of searches, but it does show the comparative values against other search words. This study used a search word to obtain all comparative values for the coupon data and utilized these relative values for the brand popularity score of the coupons.

Because the users were in their early twenties, on average, the average product price was 9,000 KRW (around 8 USD). The average product price for the buy-one-get-one-free coupons is around 4,000 KRW (3-4 USD), which is lower than the average product price for the bonus coupons. Because buy-one-get-one-free coupons provide another product of the same kind for free, the product prices and face values are the same. On average, buy-one-get-one-free coupons were issued more often than bonus coupons. Whereas the average redemption rate is greater for bonus coupons, 
brand popularity is higher for buy-one-get-one-free coupons. Table 2 shows the values of the correlation coefficients among the variables used in this paper.

Table 2: Correlation coefficients

\begin{tabular}{|l|l|l|l|l|}
\hline Variable & $\begin{array}{l}\text { Number of } \\
\text { coupons issued }\end{array}$ & $\begin{array}{l}\text { Redemption } \\
\text { rate }\end{array}$ & Face value & Price \\
\hline $\begin{array}{l}\text { Number of coupons } \\
\text { issued }\end{array}$ & 1.000 & & & \\
\hline Redemption rate & 0.153 & 1.000 & & \\
\hline Face value & 0.051 & 0.122 & 1.000 & \\
\hline Price & -0.001 & 0.069 & 0.552 & 1.000 \\
\hline Brand popularity & 0.073 & -0.057 & -0.051 & -0.013 \\
\hline
\end{tabular}

No variables were highly correlated, as Table 2 illustrates, and the values of the variance inflation factor for the analysis models are lower than 2 . Thus, the variables in Table 2 were used for further analyses.

\subsection{Data Analysis}

Since the number of coupons issued is a count variable, Poisson regression analysis was first applied to test the hypotheses. However, the dependent variables were too dispersed to apply Poisson regression, so negative binomial regression was applied [15]. Negative binomial regression is a generalization of Poisson regression, which has an extra parameter to model the over-dispersed count data and has the same mean structure as Poisson regression [15]. The negative binomial regression tests were conducted using the MASS package in R [71]. Moreover, a standardized number of issuing days, face value, price, and brand popularity were used for the tests. Because the days of coupon issue affect the number of coupons issued, it was used as a control variable. The bonus-type and buy-one-get-onefree-type coupons were tested separately. Because the product prices and face values for the buy-one-get-one-free coupons were the same, it was not possible to use those two variables together in the regression analyses. Hence, the data were separated according to coupon type, and the hypotheses for each coupon type were tested.

\subsection{Analysis Results}

Tables 3 and 4 show the results of the analysis for the bonus coupons. The dependent variable of Model 1 in Table 3 is the number of coupons issued. Since we applied negative binomial regression, we used a likelihood ratio test to compare the Poisson regression and negative binomial regression models [15]. The associated value estimated from the test is chi-squared $=93,978.86, n=2,662, d f=1$. This value strongly suggests that the negative binomial model, estimating the dispersion parameter, is more appropriate than the Poisson model. Face value and brand popularity positively affected the number of coupons issued, while product price negatively affected the number of coupons issued. The dependent variable of Model 2 in Table 4 is the redemption rate of issued coupons. Because the dependent variable is censored, Tobit regression was applied using the VGAM package in R [74]. In Model 2, face value positively affected the redemption rate. However, product price and brand popularity negatively affected the redemption rate.

Table 3: Analysis results for bonus coupons - Model 1

\begin{tabular}{|l|l|l|l|l|l|}
\hline Model 1 - Negative binomial regression \\
\hline Dependent variable & Number of coupons issued \\
\hline & Estimate & Standard Error & z-value & p-value & Confidence interval \\
\hline Days of coupon issue & 0.6769 & 0.010 & 64.561 & $<0.001$ & $(0.658,0.695)$ \\
\hline Face value & 0.1967 & 0.021 & 9.273 & $<0.001$ & $(0.157,0.235)$ \\
\hline Product price & -0.0596 & 0.017 & -3.486 & $<0.001$ & $(-0.089,-0.028)$ \\
\hline Brand popularity & 0.0847 & 0.009 & 9.217 & $<0.001$ & $(0.058,0.112)$ \\
\hline
\end{tabular}

(Note. $n=2,662$ )

Table 4: Analysis results for bonus coupons - Model 2

\begin{tabular}{|l|l|l|l|l|l|}
\hline Model 2 - Tobit regression \\
\hline $\begin{array}{l}\text { Dependent } \\
\text { variable }\end{array}$ & Redemption rate & Standard Error & z-value & p-value & $\begin{array}{l}\text { Confidence } \\
\text { interval }\end{array}$ \\
\hline & Estimate & & & & $(0.048,0.071)$ \\
\hline Face value & 0.0597 & 0.005 & 10.114 & $<0.001$ & $(-0.040,-0.022)$ \\
\hline Product price & -0.0315 & 0.004 & -6.646 & $<0.001$ & $(-0.012,-0.002)$ \\
\hline Brand popularity & -0.0072 & 0.002 & -2.771 & 0.005 &
\end{tabular}

(Note. $n=2,662$ ) 
Tables 5 and 6 show the results of the analysis for the buy-one-get-one-free coupons. Because the face value and product price of buy-one-get-one coupons are the same, the price variable was excluded from the analysis. We also use a likelihood ratio test as we did for Table 3. The associated value estimated from the test is chi-squared $=82,881.87$, $\mathrm{n}=531$, $\mathrm{df}=1$. This also strongly suggests that the negative binomial model is more appropriate than the Poisson model. For buy-one-get-one-free coupons, the effects of face value on coupons issued and redemption are the same as the results in Table 3. However, the effects of brand popularity on coupons issued and redemption rate are not significant in Tables 5 and 6 .

Table 5: Analysis results for buy-one-get-one-free coupons - Model 1

\begin{tabular}{|l|l|l|l|l|l|}
\hline Model 1 - Negative binomial regression \\
\hline $\begin{array}{l}\text { Dependent } \\
\text { variable }\end{array}$ & \multicolumn{2}{|l|}{ Number of coupons issued } \\
\hline & Estimate & Standard Error & z-value & p-value & $\begin{array}{l}\text { Confidence } \\
\text { interval }\end{array}$ \\
\hline $\begin{array}{l}\text { Days of } \\
\text { coupon } \\
\text { issue }\end{array}$ & 0.6197 & 0.038 & 16.098 & $<0.001$ & $(0.556,0.683)$ \\
\hline Face value & 0.1765 & 0.080 & & & \\
\hline $\begin{array}{l}\text { Brand } \\
\text { popularity }\end{array}$ & -0.1232 & 0.062 & 2.198 & 0.027 & $(0.025,0.421)$ \\
\hline
\end{tabular}

(Note. $n=531$ )

Table 6: Analysis results for buy-one-get-one-free coupons - Model 2

\begin{tabular}{|l|l|l|l|l|l|}
\hline Model 2 - Tobit regression \\
\hline $\begin{array}{l}\text { Dependent } \\
\text { variable }\end{array}$ & \multicolumn{2}{|l|}{ Redemption rate } \\
\hline & Estimate & Standard Error & z-value & p-value & $\begin{array}{l}\text { Confidence } \\
\text { interval }\end{array}$ \\
\hline Face value & 0.0503 & 0.013 & 3.692 & $<0.001$ & $(0.023,0.077)$ \\
\hline $\begin{array}{l}\text { Brand } \\
\text { popularity }\end{array}$ & 0.0114 & 0.010 & 1.073 & 0.283 & $(-0.009,0.032)$ \\
\hline \\
(Note. $\mathrm{n}=531)$
\end{tabular}

Table 7 shows the test results for the hypotheses. Most of the hypotheses were accepted, but the hypotheses regarding the effect of brand popularity on redemption rate were not supported.

Table 7: Results of hypotheses testing

\begin{tabular}{|c|c|c|c|}
\hline \multirow{2}{*}{\multicolumn{2}{|c|}{ Hypotheses }} & \multicolumn{2}{|l|}{ Results } \\
\hline & & \multirow{2}{*}{$\begin{array}{l}\text { Bonus-type } \\
\text { Supported }\end{array}$} & \multirow{2}{*}{$\begin{array}{l}\text { Buy-one- } \\
\text { get-one- } \\
\text { free } \\
\text { Supported }\end{array}$} \\
\hline \multirow{2}{*}{$\mathrm{H} 1$} & $\begin{array}{l}\text { The face value of a mobile bonus coupon positively affects the } \\
\text { likelihood that consumers will acquire the coupon. }\end{array}$ & & \\
\hline & $\begin{array}{l}\text { The face value of a mobile bonus coupon positively affects the } \\
\text { likelihood that consumers will redeem the coupon. }\end{array}$ & Supported & Supported \\
\hline \multirow{2}{*}{$\mathrm{H} 2$} & $\begin{array}{l}\text { The price of products for purchase with a mobile bonus coupon } \\
\text { negatively affects the likelihood that consumers will acquire the } \\
\text { coupon. }\end{array}$ & Supported & - \\
\hline & $\begin{array}{l}\text { The price of products for purchase with a mobile bonus coupon } \\
\text { negatively affects the likelihood that consumers will redeem the } \\
\text { coupon. }\end{array}$ & Supported & - \\
\hline \multirow{2}{*}{ H3 } & $\begin{array}{l}\text { The brand popularity of a product on a mobile bonus coupon } \\
\text { positively affects the likelihood that consumers will acquire the } \\
\text { coupon. }\end{array}$ & Supported & $\begin{array}{l}\text { Not } \\
\text { supported }\end{array}$ \\
\hline & $\begin{array}{l}\text { The brand popularity of a product on a mobile bonus coupon } \\
\text { positively affects the likelihood that consumers will redeem the } \\
\text { coupon. }\end{array}$ & $\begin{array}{l}\text { Not } \\
\text { supported }\end{array}$ & $\begin{array}{l}\text { Not } \\
\text { supported }\end{array}$ \\
\hline
\end{tabular}

\section{Discussion}

Our research question asked how coupon users respond to the functional and social values of coupons in terms of coupon acquisition and redemption. In this study, we examined 3,193 bonus coupons concerning the acquisition and 
redemption of coupons from a mobile coupon app. Our examination yielded three main findings. First, we found that the face value of a coupon positively influences the number of coupons issued and the redemption rate for both bonus and buy-one-get-one-free coupons. This result confirms the findings of earlier studies of traditional paper coupons [13], [56] and mobile coupons [21], [27], [31], [35]. In earlier studies, the usual dependent variables were an attitude or behavioral intention to use coupons [31] or redemption rate [13], [56]. The effect of face value on the number of coupons issued was also confirmed. A higher face value causes a higher number of coupons to be released and increases the redemption rate.

Second, price negatively affects both the number of coupons issued and the redemption rate for bonus coupons. The findings reveal that, despite the functional utility of the price offered by the face value, the actual price still plays a significant role in purchase decisions. This result also corroborates earlier studies on paper coupons [41], [44]. For buy-one-get-one-free coupons, the product price was omitted from the analysis model because the face value and product price were the same. If product price rather than face value had been used, the result might have been different. Simply put, product price positively influences the number of coupons issued and the redemption rate. Although shoppers must pay full price for the product, they receive another product of the same type for free. The average product price for buy-one-get-one-free coupons was $3,888 \mathrm{KRW}$, which is lower than that of the bonus coupons. Thus, for buy-one-get-one-free coupons, users are not concerned about the price because it is already relatively small, and they receive the same worth back for free.

Third, the social value associated with redemption of mobile coupons based on brand popularity is effective for the number of coupons issued. H3a was significant for bonus coupons, indicating that users might seek to improve their social image by purchasing popular brands. The results confirm the findings of earlier studies on the benefits of popular products for the social image [38]. Although using coupons might seem cheap to some [3], the low level of visibility of mobile coupons could alleviate that concern. The negative result for brand popularity and redemption rates might be explained by price: some popular brands may have higher prices than customers are willing to pay even with the discount offered by the mobile coupon. Therefore, $\mathrm{H} 3 \mathrm{~b}$ is rejected as brand popularity negatively influenced the redemption rate. Interestingly, brand popularity was not significant for the number of coupons issued or the redemption rate of buy-one-get-one-free coupons. Coupon users are indifferent to the brand if they can get another product for free. The average number of coupons issued for buy-one-get-one-free coupons is greater than the average number of bonus coupons issued.

\subsection{Implications}

This study confirms earlier studies on the motivational factors that contribute to the acquisition and redemption of coupons or reconfirms the relationships with actual data by incorporating public data from external sources [24]. Furthermore, the application of customer value theory to mobile coupon acquisition and redemption reveals both customers' behavior toward mobile coupons and their enthusiastic adoption of mobile couponing. We also found that although customers are willing to acquire and redeem mobile coupons, whether or not they do so will still depend on how useful customers perceive the coupon type to be, and this is still negatively affected by the final price of the product.

The results yield new insights for mobile marketers in suggesting that mobile coupon apps should use information pertaining to products, stores, and coupon goals to identify the appropriate coupon types and products. By assessing the price level of products and the brand popularity of stores, mobile coupon apps can suggest the most suitable types of coupon and target products [35], [36]. For example, to increase the number of coupons issued, stores should provide buy-one-get-one-free coupons for lower-priced products. However, if the store hopes to increase product sales, issuing bonus coupons will be more effective than buy-one-get-one-free coupons. Stores that are less popular should implement buy-one-get-one-free coupon promotions because brand popularity and coupon usage are not significantly correlated.

\subsection{Limitations}

The use of average values, while providing approximate values for the product price, represents one limitation of this study. As stated in the data section, the average price of all applicable products when a store offered a single coupon that could be redeemed against several products was applied. Coupon users chose several products from the stores when they used those coupons, but no precise information on what they ordered was available. Thus, the average product price in store is a reasonable substitute for the actual product price.

Another limitation is that only about half of the original dataset, which had 6,823 coupons, was used. Most stores that were not included in the analysis dataset did not have their own websites, or their product information was not described on other sites. In addition, some stores had no information about the number of searches that they received via the search portal Naver; hence, their brand popularity information was unavailable. Therefore, those stores were eliminated from the dataset.

Furthermore, we used only the dataset from one mobile coupon service provider to test the hypotheses in this study. The mobile service provider can influence user behavior, for example, with respect to the number, type, and value of 
coupons that they access. Thus, caution should be exercised in generalizing this study's findings to other companies or contexts.

\section{Conclusion}

The rise in mobile couponing is not simply a change from paper to digital but involves a dramatic transformation of the entire couponing process. Not only has the format for couponing changed, but the entire process has been simplified and made more accessible. Thus, further insights into users' motivations for using mobile coupon apps and the influences of various factors on coupon usage are required. In this study, this need was addressed, and the ways in which coupon users' responses to mobile bonus coupons depend on face value, product price, and brand popularity were investigated based on data collected from a mobile coupon app. The findings of this study are that the functional (face value and product price) and social (brand popularity) values are essential facets of customer value for mobile bonus coupons. The positive effect of face value and negative effect of product price was asserted, and the complex role played by social value in coupon acquisition and redemption was also identified. Also, the effects of customer value differed according to the coupon types analyzed. These findings confirm the results of previous studies on the impact of functional and social value with the actual usage data. Our findings promote the development of theories for coupon use with the aim of understanding how coupon users respond to coupons' functional and social values. Future research could investigate the interaction effects between functional and social values for coupon acquisition and redemption. And these effects will be very different according to diverse coupon types. Thus, it needs to be tested with more types of coupons. Also, the presentation of the coupons to users may have influenced their choices. The presentation includes the characteristics of the coupon itself, such as images and text, and personalized suggestions tailored to each individual. Future research could, therefore, focus on testing the effects of presentation on coupon use.

\section{Acknowledgment}

This work was supported by the Ministry of Education of the Republic of Korea and the National Research Foundation of Korea (NRF-2017S1A3 A2066740), and Hong Joo Lee was supported by the Catholic University of Korea, Research Fund, 2020

\section{References}

[1] B. L. Alford and A. Biswas, The effects of discount level, price consciousness and sale proneness on consumers' price perception and behavioral intention, Journal of Business, vol. 55, no. 9, pp. 775-783, 2002.

[2] M. Andrews, J. Goehring, S. Hui, J. Pancras, and L. Thornswood, Mobile promotions: A framework and research priorities, Journal of Interactive Marketing, vol. 34, pp. 15-24, 2016.

[3] L. Ashworth, P. R. Darke and M. Schaller, No one wants to look cheap: Trade-offs between social disincentives and the economic and psychological incentives to redeem coupons, Journal of Consumer Psychology, vol. 15, no. 4, pp. 295-306, 2005.

[4] B. J. Babin, W. R. Darden and M. Griffin, Work and/or fun: measuring hedonic and utilitarian shopping value, Journal of Consumer Research, vol. 20, no. 4, pp. 644-656, 1994.

[5] T. J. Bacile and R. E. Goldsmith, A service perspective for text message coupon customization, Journal of Research in Interactive Marketing, vol. 5, no. 4, pp. 244-257, 2011.

[6] R. P. Bagozzi, H. Baumgartner and Y. Yi, State versus action orientation and the theory of reasoned action: An application to coupon usage, Journal of Consumer Research, vol. 18, no. 4, pp. 505-518, 1992.

[7] W. E. Baker and R. J. Lutz, An empirical test of an updated relevance-accessibility model of advertising effectiveness, Journal of Advertising, vol. 29, no. 1, pp. 1-14, 2000.

[8] S. Banerjee, Effect of product category on promotional choice: comparative study of discounts and freebies, Management Research News, vol. 32, no. 2, pp. 120-131, 2009.

[9] S. Banerjee and S. Yancey, Enhancing mobile coupon redemption in fast food campaigns, Journal of Research in Interactive Marketing, vol. 4, no. 2, pp. 97-110, 2010.

[10] S. Banerjee, A. Poddar, S. Yancey, and D. McDowell, Measuring intangible effects of m-coupon campaigns on non-redeemers, Journal of Research in Interactive Marketing, vol. 5, no. 4, pp. 258-275, 2011

[11] S. Banerjee and R. R. Dholakia, Location-based mobile advertisements and gender targeting, Journal of Research in Interactive Marketing, vol. 6, no. 3, pp. 198-214, 2012.

[12] H. Bauer, S. J. Barnes, M. Neumann, and T. Reichardt, Driving consumer acceptance of mobile marketing: A theoretical framework and empirical study, Journal of Electronic Commerce Research, vol. 6, no. 3, pp. 181-192, 2005.

[13] K. Bawa and R. W. Shoemaker, Analyzing incremental sales from a direct mail coupon promotion, Journal of Marketing, vol. 53, no. 3, pp. 66-78, Jul 1989.

[14] I. Beeck and W. Toporowski, When location and content matter: Effects of mobile messages on intention to redeem, International Journal of Retail \& Distribution Management, vol. 45, no. 7/8, pp. 826-843, 2017.

[15] C. Cameron and P. K. Trivedi, Regression Analysis of Count Data Book, 2nd ed. Cambridge University Press, 2013. 
[16] R. L. Celsi and J. C. Olson, The role of involvement in attention and comprehension processes, Journal of Consumer Research, vol. 15, no. 2, pp. 210-224, 1988

[17] P. Chandon, B. Wansink and G. Laurent, A benefit congruency framework of sales promotion effectiveness, Journal of Marketing, vol. 64, no. 4, pp. 65-81, 2000.

[18] S. Chandran and V. G. Morwitz, The price of free-dom: consumer sensitivity topromotions with negative contextual influences, Journal of Consumer Research, vol. 33, no. 1, pp. 384-392, 2006.

[19] Consumer Reports. (2013, August) Best Coupon Apps for Grocery Shopping. [Online]. Available: https://consumerreports.org/2013/08/best-coupon-apps/index.htm

[20] W. D. Diamond, Just what is a dollar's worth? Consumer reactions to price discounts vs. extra product promotions Journal of Retailing, vol. 68, no. 3, pp. 254-270, 1992.

[21] A. Dickinger and M. Kleijnen, Coupons going wireless: Determinants of consumer intentions to redeem mobile coupons, Journal of Interactive Marketing, vol. 22, no. 3, pp. 23-39, 2008.

[22] W. B. Dodds, K. B. Monroe and D. Grewal, The effects of price, brand and store information on buyers' product evaluations, Journal of Marketing Research, vol. 28, no. 3, pp. 307-319, 1991.

[23] R. W. Easley, C. S. Madden and M. G. Dunn, Conducting marketing science: The role of replication in the research process, Journal of Business Research, vol. 48, no. 1, pp. 83-92, 2000.

[24] A. Ghose, A. Goldfarb and S. P. Han, How is the mobile internet different? Search costs and local activities, Information Systems Research, vol. 24, no. 3, pp. 613-631, 2013.

[25] E. Gonzalez, Exploring the effect of coupon proneness and redemption efforts on mobile coupon redemption intentions, International Journal of Marketing Studies, vol. 8, no. 6, pp. 1-6, 2016

[26] A. Greenstein-Messica, L. Rokach and A. Shabtai, Personal-discount sensitivity prediction for mobile coupon conversion optimization, Journal of the Association for Information Science and Technology, vol. 68, no. 8, pp. 1940-1952, 2017.

[27] Y. Ha and H. Im, Determinants of mobile coupon service adoption: Assessment of gender difference, International Journal of Retail \& Distribution Management, vol. 42, no. 5, pp. 441-459, 2014.

[28] C. M. Henderson, Modeling the Coupon Redemption Decision, ACR North American Advances, 1985.

[29] S. Hui, J. Inman, Y. Huang, and J. Suher, Estimating the effect of travel distance on unplannedspending: Applications to mobile promotion strategies, Journal of Marketing, vol. 77, no. 2, pp. 1-16, 2013.

[30] H. Im and Y. Ha, Who are the users of mobile coupons? A profile of US consumers, Journal of Research in Interactive Marketing, vol. 6, no. 3, pp. 215-232, 2012.

[31] H. Im and Y. Ha, Enablers and inhibitors of permission-based marketing: A case of mobile coupons Journal of Retailing and Consumer Services, vol. 20, no. 5, pp. 495-503, 2013.

[32] J. J. Inman and L. McAlister, Do coupon expiration dates affect consumer behavior?, Journal of Marketing Research, vol. 31, no. 3, pp. 423-428, 1994.

[33] A. Janson, A. Hoffmann, H. Hoffmann, and J. M. Leimeister, How customers trust Mobile marketing applications?, in Proceedings Thirty Fourth International Conference on Information Systems, Milan, Italy, 2013, p. 13.

[34] C. Jayawardhena, A. Kuckertz, H. Karjaluoto, and T. Kautonen, Antecedents to permission based mobile marketing: an initial examination, European Journal of Marketing, vol. 43, no. 3/4, pp. 473-499, 2009.

[35] S. Khajehzadeh, H. Oppewal and D. Tojib, Consumer responses to mobile coupons: The roles of shopping motivation and regulatory fit, Journal of Business Research, vol. 67, no. 11, pp. 2447-2455, 2014.

[36] S. Khajehzadeh, H. Oppewal and D. Tojib, Mobile coupons: What to offer, to whom, and where?, European Journal of Marketing, vol. 49, no. 5/6, pp. 851-873, 2015

[37] H.-W. Kim, H. C. Chan and S. Gupta, Value-based adoption of mobile internet: An empirical investigation, Decision Support Systems, vol. 43, no. 1, pp. 111-126, 2007.

[38] H.-W. Kim, S. Gupta and J. Koh, Investigating the intention to purchase digital items in social networking communities: A customer value perspective, Information \&amp; Management, vol. 48, no. 6, pp. 228-234, 2011.

[39] H. J. Kim and H. Song, Effort justification for fun activities?: The effect of location-based mobile coupons using games, Journal of Retailing and Consumer Services, vol. 54, Article no. 102029, 2020.

[40] F. N. Kondo, Y. Uwadaira and M. Nakahara, Stimulating customer response to promotions: The case of mobile phone coupons, Journal of Targeting, Measurement and Analysis for Marketing, vol. 16, no. 1, pp. 57-67, 2007.

[41] J.-Y. Lee, The effect of price on coupon redemption: A case study of florida orange juice industry coupon programs southern, Journal of Agricultural Economics, vol. 14, no. 1, pp. 125-130, 1982.

[42] W.-j. Lee, Unravelling consumer responses to omni-channel approach, Journal of Theoretical and Applied Electronic Commerce Research, vol. 15, no. 3, pp. 37-49, 2020.

[43] J. W. Levedahl, Coupon redeemers: Are they better shoppers?, Journal of Consumer Affairs, vol. 22, no. 2, pp. 264-283, 1988.

[44] D. R. Lichtenstein, N. M. Ridgway and R. G. Netemeyer, Price perceptions and consumer shopping behavior: A field study, Journal of Marketing Research, vol. 30, no. 2, pp. 234-245, 1993.

[45] X. Luo, M. Andrews, Z. Fang, and C. W. Pang, The effects of mobile targeting, in Proceedings Thirty Fourth International Conference on Information Systems, Milan, Italy, 2013, p. 1.

[46] S. P. Mantel and J. Kellaris, Cognitive determinants of consumers' time perceptions: The impact of resources required and available, Journal of Consumer Research, vol. 29, no. 4, pp. 531-538, 2003.

[47] P. Mills and C. Zamudio, Scanning for discounts: Examining the redemption of competing mobile coupons, Journal of the Academy of Marketing Science, vol. 46, pp. 964-982, 2018.

[48] B. Mittal, An integrated framework for relating diverse consumer characteristics to supermarket coupon redemption, Journal of Marketing Research, vol. 31, no. 4, pp. 533-544, 1994. 
[49] Mobile Marketing Association. (2007, April) Introduction to mobile coupons. Maglobal. [Online]. Available: https://www.mmaglobal.com/files/mobilecoupons.pdf

[50] J. L. Munger and D. Grewal, The effects of alternative price promotional methods on consumes' product evaluations and purchase intentions, Journal of Product and Brand Management, vol. 10, no. 3, pp. 185-197, 2001.

[51] P. Nayal and N. Pandey, Redemption intention of coupons: A meta-analytical review and Future Directions, Journal of Promotion Management, vol. 26, no. 3, pp. 372-395, 2020.

[52] J. C. Nunes and C. W. Park, Incommensurate resources: Not just more of the same, Journal of Marketing Research, vol. 40, no. 1 , pp. 26-38, 2003.

[53] S. Okazaki, Searching the web for global brands: How do American brands standardize their websites in Europe?, European Journal of Marketing, vol. 39, no. 1/2, pp. 87-109, 2005.

[54] J. K. Philip, Coupon redemption behaviour: A Malaysian cross-segment investigation, Marketing Intelligence \& Planning, vol. 32, no. 1, pp. 66-88, 2014.

[55] M. Raskino, Mobile Coupons will Reach Right into your Pocket, Gartner Group Research Note, 2001.

[56] D. J. Reibstein and P. A. Traver, Factors affecting coupon redemption rates, Journal of Marketing, vol. 46, no. 4, pp. 102-113, 1982.

[57] A. Scharl, A. Dickinger and J. Murphy, Diffusion and success factors of mobile marketing, Electronic Commerce Research and Applications, vol. 4, no. 2, pp. 159-173, 2005.

[58] R. M. Schindler, The excitement of getting a bargain: Some hypotheses concerning the origins and effects of smart-shopper feelings, Advances in Consumer Research, vol. 16, no. 1, pp. 447-453, 1989

[59] R. M. Schindler, Consequences of perceiving oneself as responsible for obtaining a discount: Evidence for smartshopper feelings, Journal of Consumer Psychology, vol. 7, no. 4, pp. 371-392, 1998.

[60] V. Shankar, A. Venkatesh, C. Hofacker, and P. Naik, Mobile marketing in the retailing environment: Current insights and future research avenues, Journal of Interactive Marketing, vol. 124, no. 2, pp. 111-120, 2010.

[61] J. Sheth, B. Newman and B. Gross, Why we buy what we buy: A theory of consumption values, Journal of Business Research, vol. 22, no. 2, pp. 159-170, 1991.

[62] T. A. Shimp and A. Kavas, The theory of reasoned action applied to coupon usage, Journal of Consumer Research, vol. 11, no. 3, pp. 795-809, 1984.

[63] N. Souiden, W. Chaouali and M. Baccouche, Consumers' attitude and adoption of location-based coupons: The case of the retail fast food sector, Journal of Retailing and Consumer Services, vol. 47, pp. 116-132, 2019.

[64] S. Spiekermann, M. Rothensee and M. Klafft, Street marketing: How proximity and contextdrive coupon redemption, Journal of Consumer Marketing, vol. 28, no. 4, pp. 280-289, 2011.

[65] G. J. Stigler, The development of utility theory, Journal of Political Economy, vol. 58, no. 4, pp. 307-327, 1950.

[66] F. Sultan and A. J. Rohm, An exploratory cross-market study of mobile marketing acceptance, International Journal of Mobile Marketing, vol. 1, no. 1, pp. 2-10, 2006.

[67] S. Swaminathan and K. Bawa, Category-specific coupon proneness: The impact of individual characteristics and category-specific variables, Journal of Retailing, vol. 81, no. 3, pp. 205-214, 2005.

[68] J. C. Sweeney and G. N. Soutar, Consumer perceived value: The development of a multiple item scale, Journal of Retailing, vol. 77, no. 2, pp. 203-220, 2001.

[69] J. Tähtinen, Mobile advertising or mobile marketing. A need for a new concept?, in Proceedings Frontiers of Ebusiness Research Conference, Tampere, Finland, 2005, pp. 152-164.

[70] Q. Tang, F. Liu, S. Liu, and Y. Ma, Consumers' redemption behavior of recommended mobile coupons in social network sites, Management Decision, vol. 57, no. 9, pp. 2477-2500, 2019.

[71] W. N. Venables and B. D. Ripley, Random and mixed effects. In: Modern Applied Statistics with S. Statistics and Computing. New York, NY: Springer, 2002.

[72] P. Verhoef et al., CRM in data-rich multichannel retailing environments, Journal of Interactive Marketing, vol. 24, no. 2, pp. 121-137, 2010.

[73] H. Xu, H.-H. Teo and B. Tan, Predicting the adoption of location-based services: The role of trust and perceived privacy risk, in Proceedings International Conference on Information Systems (ICIS), Las Vegas, NV, 2005, p. 71.

[74] T. W. Yee, Vector Generalized Linear and Additive Models: With an Implementation in R. Springer-Verlag New York, 2015.

[75] V. A. Zeithaml, Consumer perceptions of price, quality and value: A means-end model and synthesis of evidence, Journal of Marketing, vol. 52, no. 3, pp. 2-22, 1988. 